УДК 631.51:631.44:622.023.2

Центило Л. В., кандидат сільськогосподарських наук, Цюк О. А., доктор сільськогосподарських наук

Національний університет біоресурсів і природокористування України

\title{
ДИНАМІКА ЗМІН ТВЕРДОСТІ ГРУНТУ ЗАЛЕЖНО ВІД ЙОГО ОСНОВНОГО ОБРОБІТКУ
}

\author{
Рецензент - доктор сільськогосподарських наук А. Д. Балаєв
}

Мета статті - виявити залежності зміни динаміки твердості грунту за застосування різних систем основного обробітку.

Методика дослідження. Методологічною основою слугували такі наукові методи: аналіз, синтез, польовий, статистичний.

Результати досліджень. У статті наведено результати досліджень на чорноземі типовому глибокому Правобережного Лісостепу України щзодо вивчення трунтозахисної ефективності варіантів основного обробітку на твердість трунту. 3'ясовано, щьо полицевий обробіток не змінює діапазону твердості в чорноземі типовому.

Застосування мілкого безполицевого обробітку зі шілюванням викликає збільшення твердості в нижній частині орного шару трунту. Відмінності за твердістю найбільш виражені восени, відразу після проведення основного обробітку, а у весняно-літній період вони згладжують $i$, як правило, не досягають критичних значень для вирощування культур.

Елементи наукової новизни. Доведено, що твердість чорнозему типового глибокого малогумусного зазнає змін залежно від систем основного обробітку грунту. Застосування полицевого обробітку не змінює показники твердості трунту. Визначено, що мілкий безполицевий обробіток із одночасним щілюванням збільшує величину твердості в нижній частині орного шару трунту.

Практична значущість. Вивчення динаміки змін твердості трунту щодо систем основного обробітку трунту здійснювалося на дослідному полі Навчально-науково-інновачійного центру агротехнологій ТОВ «Агрофірма Колос» (2011-2017 рр.) Сквирського району Київської області у стаціонарному досліді. Розмір посівної ділянки - 340 м² $^{2}$ обліковий - $195 \mathrm{M}^{2}$. Повторність триразова. Встановлено, що застосування полищевого обробітку в сівозміні не змінює показника твердості трунту. Застосування мілкого безполицевого обробітку одночасно із щілюванням призводить до збільшення твердості трунту в середньому за вегетащію кукурудзи на зерно на 27 \%, люиерни 1,74 \% порівняно із систематичним полицевим обробітком. Проте у посівах пшениці озимої показник твердості трунту за мілкого безполицевого із одночасним щілюванням знижувався на $14,3 \%$ порівняно із поличевим обробітком.

Ключові слова: твердість, система обробітку, чорнозем типовий, трунт.

Центило Леонід Васильович - кандидат сільськогосподарських наук, Національний університет біоресурсів і природокористування України, вул. Героїв Оборони, 15, м. Київ, 03041, Україна, е-таil: tsyuk@ukr.net.

Цюк Олексій Анатолійович - доктор сільськогосподарських наук, Національний університет біоресурсів і природокористування України, вул. Героїв Оборони, 15, м. Київ, 03041, Україна, е-таil: tsyuk@ukr.net.

Постановка проблеми. Головним завданням в обробітку грунту є створення оптимальних умов для вирощування культур. Важливого значення тут набувають такі агрофізичні показники, як щільність складення та твердість грунту [4].

Твердість $є$ одним із основних показників, за яким характеризують фізичний стан грунту, оцінюють середовище, у якому росте і розвивається рослина. Підвищення показника твердості спри- чиняє зростання енергоємності заходів обробітку грунту, погіршує умови появи сходів рослин на поверхні грунту. Високий рівень твердості грунту, особливо сухого, є значною перешкодою росту і розвитку кореневої системи рослин $[7,11]$.

Аналіз останніх досліджень і публікацій, у яких започатковано розв'язання цісї проблеми. Завдяки тривалим дослідженням В. В. Медведєва з'ясовано, що високі показники твердості 


\section{СІЛЬСЬКЕ ГОСПОДАРСТВО. ЕКОЛОГІЯ}

спричиняють низьку водопроникність грунту, обмежений ріст та розвиток коренів сільськогосподарських культур, зріджені та недружні сходи, низький рівень урожайності [9]. Твердість грун-

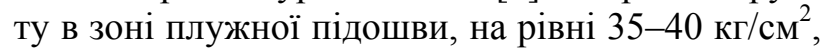
обмежує ріст коренів [2].

Відомо, що зі зменшенням вологості у грунті твердість значно зростає і негативно діє на культурні рослини [6].

Н. А. Качинський [5] одним із перших звернув увагу на залежність твердості грунту від запасів вологи у ньому і способу його обробітку. Він дослідив, що зі зменшенням вмісту вологи у грунті твердість значно зростає i негативно впливає на кореневу систему культурних рослин.

П. У. Бахтін [1] визначив, що твердість грунту пов'язана $з$ особливостями агрофону, глибиною обробленого шару, утворенням плужної підошви, виду культури та способу сівби. Йому вдалося встановити оптимальні значення твер-

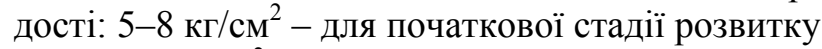

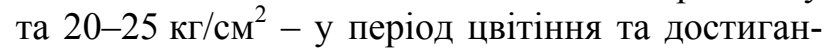
ня, що є оптимальними для сільськогосподарських культур.

Дослідженнями доведено, що для зернових колосових культур твердість грунту на рівні 20-

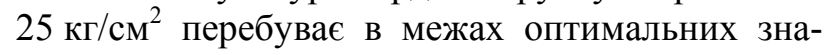
чень, тоді як для просапних та коренеплодів оптимальними є 5-10 кг/см² $[3,8]$.

Формування показників твердості грунту на

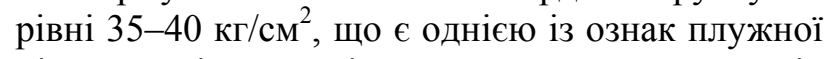
підошви, різко сповільнює проникнення коренів у нижні шари, а в окремих випадках взагалі припиняє [10].

Для умов Лісостепу на чорноземах типових глибоких ефективність безполицевих обробітків i3 одночасним щілюванням грунту вивчено недостатньо.

Мета досліджень - виявити залежності зміни динаміки твердості грунту за застосування різних систем основного обробітку. Завдання дослідження - встановити показники динаміки зміни твердості грунту в посівах люцерни, пшениці озимої, кукурудзи на зерно.

Матеріали i методи досліджень. Експериментальну частину роботи виконано на дослідному полі Навчально-науковоінноваційного центру агротехнологій ТОВ «Агрофірма Колос» (2011-2017 pp.) Сквирського району Київської області у стаціонарному досліді, проводилася порівняльна оцінка із вивчення грунтозахисної ефективності варіантів основного обробітку грунту.

Чергування культур у досліді наступне: люцерна-пшениця озима кукурудза на зерно - ячмінь 3 підсівом люцерни:

1. Полицевий обробіток грунту - контроль.

2. Мілкий безполицевий обробіток $з$ одночасним щілюванням.

Ірунт дослідного поля - чорнозем типовий глибокий крупнопилувато-середньосуглинковий на лесі. Вміст гумусу в оброблювальному шарі 4,6-4,8 \% (за Тюриним), легкогідролізованого азоту (за Корнфілдом) - 14,4 мг/100 г грунту, рухомого фосфору (за Чиріковим) - 15,2 мг/100 г грунту, обмінного калію - 15,2 мг/100 г грунту (за Чиріковим). Об'ємна маса грунту в

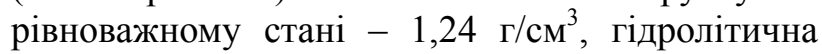
кислотність - 1,14 мг-екв./100 г грунту, $\mathrm{pH}$ сольове $-6,4$.

У контрольному варіанті основний обробіток грунту виконували ПЛН-3-35 в агрегаті із кільчасто-шпоровим котком, під пшеницю озиму на глибину 20-22 см, кукурудза на зерно - 2527 см, ячмінь - 20-22 см.

У другому варіанті основний обробіток грунту проводили на 10-12 см із щілюванням на 35-40 см плоскорізом-щілювачем ПЩН-2,5.

Розміщення варіантів систематичне, розмір посівної ділянки $8,5 * 40=340 \mathrm{~m}^{2}$, обліковий $6,5 * 30=195 \mathrm{~m}^{2}$. Повторність триразова. Визначали твердість грунту за ДСТУ 5093:2008.

Результати досліджень. Визначення твердості в ланці - люцерна, пшениця озима, кукурудза на зерно показали, що найбільш стійкий у часі цей показник за вирощування люцерни, коли обробіток грунту здійснюється лише під попередник. Результати досліджень свідчать про те, що в осінній період створюється сприятливий склад грунту, оскільки його твердість в 0-20 см шарі знаходиться на рівні 15,6-19,7 кг/см². При цьому вплив обробітку грунту не проявляється (табл. 1).

У весняний період до початку відростання трав відмічається помітне зниження твердості. Причиною цього є гідротермічні фактори i, насамперед, збільшення вологості грунту за осінньо-зимовий період.

Під час весняно-літньої вегетації, по мірі росту і розвитку трав відбувалося висушення грунту i, як наслідок, збільшувалися показники твердості грунту. 


\section{1. Вилив систем обробітку грунту на твердість чорнозему типового} за вирощування люцерни, ке/с. ${ }^{2}$

\begin{tabular}{|c|c|c|c|c|c|}
\hline \multirow[b]{2}{*}{$\begin{array}{l}\text { Варіант обро- } \\
\text { бітку грунту }\end{array}$} & \multirow[b]{2}{*}{$\begin{array}{c}\text { Шар } \\
\text { грунту, см }\end{array}$} & \multicolumn{4}{|c|}{ Фаза визначення } \\
\hline & & $\begin{array}{c}\text { після зби- } \\
\text { рання попере- } \\
\text { дника }\end{array}$ & $\begin{array}{c}\text { початок } \\
\text { відновлення } \\
\text { вегетації }\end{array}$ & цвітіння & $\begin{array}{l}\text { перед зби- } \\
\text { ранням }\end{array}$ \\
\hline \multirow{5}{*}{$\begin{array}{l}\text { Полицевий } \\
\text { обробіток }\end{array}$} & $0-5$ & 16,0 & 12,8 & 16,9 & 17,6 \\
\hline & $5-10$ & 16,1 & 13,9 & 17,4 & 18,1 \\
\hline & $10-15$ & 18,6 & 16,6 & 19,0 & 18,5 \\
\hline & $15-20$ & 18,8 & 16,7 & 19,2 & 18,7 \\
\hline & $20-25$ & 20,4 & 17,4 & 20,7 & 19,0 \\
\hline \multirow{5}{*}{$\begin{array}{c}\text { Мілкий без- } \\
\text { полицевий обро- } \\
\text { біток із одночас- } \\
\text { ним щілюванням }\end{array}$} & $0-5$ & 15,6 & 11,9 & 16,7 & 17,9 \\
\hline & $5-10$ & 16,0 & 13,0 & 18,4 & 17,9 \\
\hline & $10-15$ & 17,9 & 16,0 & 18,7 & 19,9 \\
\hline & $15-20$ & 19,7 & 16,6 & 19,0 & 20,2 \\
\hline & $20-25$ & 21,6 & 18,7 & 22,2 & 20,8 \\
\hline \multicolumn{2}{|c|}{$\mathrm{HIP}_{05}$ обробіток грунту } & $\mathrm{F}_{\phi}<\mathrm{F}_{05}$ & $\mathrm{~F}_{\phi}<\mathrm{F}_{05}$ & $\mathrm{~F}_{\phi}<\mathrm{F}_{05}$ & $\mathrm{~F}_{\phi}<\mathrm{F}_{05}$ \\
\hline \multicolumn{2}{|c|}{ HIP $_{05}$ шар грунту } & 2,3 & 1,0 & 2,26 & 1,32 \\
\hline
\end{tabular}

Джерело: власні дослідження.

\section{2. Вилив систем основного обробітку трунту на твердість чорнозему типового за вирощування пшениці озимої, кг/см ${ }^{2}$}

\begin{tabular}{|c|c|c|c|c|c|}
\hline \multirow{2}{*}{$\begin{array}{l}\text { Варіант обро- } \\
\text { бітку грунту }\end{array}$} & \multirow{2}{*}{$\begin{array}{c}\text { Шар } \\
\text { грунту, см }\end{array}$} & \multicolumn{4}{|c|}{ Фаза визначення } \\
\hline & & перед сівбою & $\begin{array}{l}\text { відновлення } \\
\text { вегетації }\end{array}$ & цвітіння & $\begin{array}{l}\text { перед зби- } \\
\text { ранням }\end{array}$ \\
\hline \multirow{5}{*}{$\begin{array}{l}\text { Полицевий } \\
\text { обробіток }\end{array}$} & $0-5$ & 12,8 & 8,8 & 13,8 & 18,7 \\
\hline & $5-10$ & 15,1 & 9,3 & 14,5 & 19,6 \\
\hline & $10-15$ & 16,5 & 9,8 & 16,0 & 19,6 \\
\hline & $15-20$ & 16,7 & 13,4 & 17,1 & 20,9 \\
\hline & $20-25$ & 20,7 & 18,6 & 20,7 & 22,2 \\
\hline \multirow{5}{*}{$\begin{array}{c}\text { Мілкий без- } \\
\text { полицевий обро- } \\
\text { біток із одночас- } \\
\text { ним щілюванням }\end{array}$} & $0-5$ & 13,0 & 8,9 & 15,8 & 17,6 \\
\hline & $5-10$ & 15,5 & 9,6 & 16,0 & 19,0 \\
\hline & $10-15$ & 21,0 & 10,9 & 17,5 & 20,2 \\
\hline & $15-20$ & 21,2 & 15,1 & 19,3 & 20,1 \\
\hline & $20-25$ & 22,2 & 20,5 & 20,8 & 21,3 \\
\hline \multicolumn{2}{|c|}{ НIP $_{05}$ обробіток грунту } & 0,39 & $\mathrm{~F}_{\phi}<\mathrm{F}_{05}$ & 1,42 & $\mathrm{~F}_{\phi}<\mathrm{F}_{05}$ \\
\hline \multicolumn{2}{|c|}{ HIP $_{05}$ шар грунту } & 1,72 & 1,76 & 2,41 & 2,06 \\
\hline
\end{tabular}

Джерело: власні дослідження.

До фази цвітіння складення грунту досягло рівноважного стану, а твердість в 0-20 см шарі становила $16,7-19,2$ кг/см² і не перевищувала допустимих значень. На час збирання змін твердості грунту не спостерігалося. Не встановлено також вплив післядії оранки і безполицевого обробітку, що проводяться під покривну культуру.

За вирощування пшениці озимої більш високі показники твердості відмічені за мілкого безполицевого обробітку грунту в осінній період вегетації (табл. 2). Це пояснюється двома причина-

ми: різною глибиною основного обробітку i більш високою щільністю грунту в шарі 1025 см. Остання за оранки становила 1,151,23 кг/ $\mathrm{cm}^{2}$, а за мілкого безполицевого обробітку була на $0,12-0,21$ г/см² більше.

До початку весняної вегетації твердість грунту зменшилася, а вплив обробітку був послаблений. За полицевого залежно від шару грунту твердість перебувала на рівні $8,8-18,6$ кг/ $\mathrm{cm}^{2}$, а

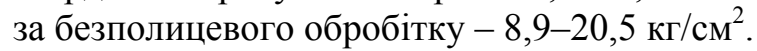




\section{СІЛЬСЬКЕ ГОСПОДАРСТВО. ЕКОЛОГІЯ}

\section{3. Вилив систем основного обробітку грунту на твердість чорнозему типового за вирощування кукурудзи на зерно, кг/см²}

\begin{tabular}{|c|c|c|c|c|c|}
\hline \multirow[b]{2}{*}{$\begin{array}{l}\text { Варіант обро- } \\
\text { бітку грунту }\end{array}$} & \multirow[b]{2}{*}{$\begin{array}{c}\text { Шар } \\
\text { грунту, см }\end{array}$} & \multicolumn{4}{|c|}{ Фаза визначення } \\
\hline & & $\begin{array}{r}\text { після прове- } \\
\text { дення основно- } \\
\text { го обробітку }\end{array}$ & сходи & $\begin{array}{l}\text { 8-10 ли- } \\
\text { стків }\end{array}$ & $\begin{array}{l}\text { перед зби- } \\
\text { ранням }\end{array}$ \\
\hline \multirow{5}{*}{$\begin{array}{l}\text { Полицевий } \\
\text { обробіток }\end{array}$} & $0-5$ & 5,9 & 5,4 & 13,8 & 18,7 \\
\hline & $5-10$ & 6,0 & 5,5 & 14,2 & 19,2 \\
\hline & $10-15$ & 7,4 & 5,8 & 16,1 & 19,6 \\
\hline & $15-20$ & 7,7 & 8,5 & 17,6 & 20,9 \\
\hline & $20-25$ & 8,3 & 9,7 & 19,4 & 21,3 \\
\hline \multirow{5}{*}{$\begin{array}{c}\text { Мілкий без- } \\
\text { полицевий обро- } \\
\text { біток із одночас- } \\
\text { ним щілюванням }\end{array}$} & $0-5$ & 6,2 & 5,8 & 15,3 & 19,8 \\
\hline & $5-10$ & 6,3 & 5,9 & 15,6 & 19,4 \\
\hline & $10-15$ & 6,4 & 10,5 & 19,0 & 20,5 \\
\hline & $15-20$ & 18,2 & 15,2 & 23,0 & 25,0 \\
\hline & $20-25$ & 19,2 & 17,0 & 24,4 & 25,3 \\
\hline \multicolumn{2}{|c|}{ HIP $_{05}$ для обробітку } & 3,64 & 2,17 & 3,13 & $\mathrm{~F}_{\phi}<\mathrm{F}_{05}$ \\
\hline \multicolumn{2}{|c|}{ HIP $_{05}$ для шару грунту } & 2,14 & 1,30 & 1,83 & 1,45 \\
\hline
\end{tabular}

Джерело: власні дослідження.

У наступні строки визначення відмічалося збільшення твердості грунту. Найбільш інтенсивно цей процес відбувався у верхній частині оброблюваного шару, де відмічалося ущільнення i висушення грунту за інтенсивного наростання кореневої системи. На глибині $15-25$ см складення грунту і умови зволоження більш стабільні, тому меншою мірою змінювалася твердість.

Можна також зазначити, що різниця за твердістю грунту, сформована восени під час проведення основного обробітку, зберігалася і у весняно-літній період вегетації пшениці озимої. Так, за мілкого безполицевого обробітку в 025 см шарі твердість була на 7-8 \% вище, ніж за полицевого обробітку. На період збирання різниці за твердості між досліджуваними варіантами не встановлено.

За вирощування кукурудзи на зерно найменші значення твердості відмічені весною. Обумовлено це високою вологістю грунту в цей період. Щільність грунту також впливала на іiі твердість. Про це свідчать показники твердості у варіанті з мілким безполицевим обробітком. На глибині 15-25 см твердість значно вище і стано-

\section{БІБЛІОГРАФІЯ}

1. Бахтин П. У. Исследование физикомеханических и технологических свойств почв СССР. Москва : Колос, 1969. 271 с.

2. Горохов П. В. Некоторые аспекты понятия «твердость почвы» применительно к исследованию процесса рыхления. Почвоведение. 1990. № 2. C. 56-57.

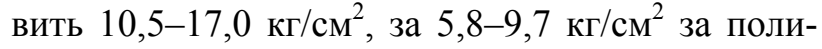
цевого обробітку (табл. 3).

За час інтенсивного росту кукурудзи твердість істотно зросла, що пов'язано з інтенсивним висушенням оброблюваного шару. На період збирання твердість зросла ще більше і у варіанті 3 мілким безполицевим обробітком на глибині 15-20 і 20-25 см на 5,0 і 5,3 кг/ $/ \mathrm{cm}^{2}$, перевищила критичні значення. У варіанті полицевого обробітку оптимальні показники були перевищені всього на $0,6-1,0$ кг $/ \mathrm{cm}^{2}$.

\section{Висновки.}

1. Полицевий обробіток не змінює діапазону твердості в чорноземі типовому.

2. Систематичне застосування мілкого безполицевого обробітку зі щілюванням спричиняє збільшення твердості в нижній частині орного шару.

3. Відмінності за твердістю найбільш виражені восени, відразу після проведення основного обробітку, а у весняно-літній період вони згладжують $\mathrm{i}$, як правило, не досягають критичних значень для вирощування культур.

3. Демиденко О. В. Післяжнивні рештки в грунтозахисному землеробстві як енергетика грунтоутворення в агроценозах Лівобережного Лісостепу України. Вісник Черкаського інституту агропромислового виробництва : Міжсвід. темат. зб. наук. пр. Черкаси, 2005. Вип. 5. C. 13-26. 


\section{СІЛЬСЬКЕ ГОСПОДАРСТВО. ЕКОЛОГІЯ}

4. Динамика плотности почвы чернозема южного при минимализации основной обработки / А. П. Солодовников, А. В. Летучий, Д. С. Степанов и др. Земледелие. 2015. № 1. C. 5-7.

5. Качинский Н. А. Физика почвы. Москва : Высш. шк., 1970. Ч. 2. 360 с.

6. Лактионова T. М. Изменение физических свойств чернозема при внесении навоза. Почвоведение. 1990. № 8. С. 73-82.

7. Лукьянчикова 3. И. Изменение элементов плодородия почвы под влиянием противоэрозионной агротехники и удобрений. Агрохимия $u$ почвоведение. 1977. Вып. 34. С. 21-29.

8. Медведев В. В. Оптимизация агрофизичес-

\section{REFERENCES}

1. Bakhtyn, P. U. (1969). Issledovanie fizikomekhanicheskikh i tekhnolohicheskikh svoistv pochv SSSR [The study of physico-mechanical and technological properties of soils of the USSR]. Moskva: Kolos [In Russian].

2. Horokhov, P. V. (1990). Nekotorye aspekty poniatyia "tverdost pochvy" primenitelno k issledovaniiu protsessa rekhleniia [Some aspects of the concept of "soil hardness" in relation to the study of the process of loosening]. Pochvovedenye, 2, pp. 56-57 [In Russian].

3. Demydenko, O. V. (2005). Pisliazhnyvni reshtky $\mathrm{V}$ gruntozakhysnomu zemlerobstvi yak enerhetyka gruntoutvorennia $\mathrm{V}$ ahrotsenozakh Livoberezhnoho Lisostepu Ukrainy [Stubble in erosion control as energy agrocenoses left bank of soil in steppes of Ukraine]. Visnyk Cherkaskoho instytutu ahropromyslovoho vyrobnytstva, 5, pp. 13-26 [In Ukrainian].

4. Solodovnikov, A. P., Letuchii, A. V., Stepanov, D. S., et al. (2015). Dynamika plotnosti pochvy chernozema iuzhnoho pri minimalizatsii osnovnoi obrabotki [The dynamics of the density of the soil of southern chernozem while minimizing the main treatment]. Zemledelye, 1, pp. 5-7 [In Russian].

5. Kachynskii, N. A. (1970). Fizika pochvy [Soil physics]. (Vol. 2). Moskva: Vy`sshaya shkola [In Russian].

6. Laktyonova, T. M. (1990). Izmenenie fizicheskikh svoistv chernozema pri vnesenii navoza ких свойств черноземов. Москва : Агропромиздат, 1988. $160 \mathrm{c.}$

9. Медведев B. В. Твердость почв. Харьков : Изд-во КП «Городская типография», 2009. 152 с.

10. Медведєв В. В., Лактіонова Т. М., Пліско I. B. Закономірності залучення гранулометричних елементів у мікроагрегати в грунтах України. Агрохімія і грунтознавство. 2001. Вип. 61. C. 22-31.

11. Шиліна Л. І., Шаповал І. Е., Срмола$\epsilon в$ M. M. Зміна структурно-агрегатного стану чорнозему типового під впливом чинників землеробства. Агрохімія $і$ трунтознавство. Міжвід. темат. наук. зб. Харків, 2006. Спец. вип., кн. 2. C. 188-190.

[Changes in the physical properties of chernozem during manure application]. Pochvovedenie, 8, pp. 73-82 [In Russian].

7. Lukianchykova, Z. Y. (1977). Izmenenie elementov plodorodiia pochvy pod vliianiem protyvotrozyonnoi ahrotekhniki i udobrenii [Change of soil fertility elements under the influence of antierosion agrotechnology and fertilizers]. Ahrokhimiia i pochvovedenie, 34, pp. 21-29 [In Russian].

8. Medvedev, V. V. (1988). Optimizatsiia ahrofizicheskikh svoistv chernozemov [Optimization of agrophysical properties of chernozem]. Moskva: Ahropromizdat [In Russian].

9. Medvedev, V. V. (2009). Tverdost pochv [Soil hardness]. Kharkov: Izd-vo KP «Horodskaia tipohrafiia» [In Russian].

10. Medvediev, V. V., Laktionova, T. M., Plisko, I. V. (2001). Zakonomirnosti zaluchennia hranulometrychnykh elementiv u mikroahrehaty $\mathrm{v}$ gruntakh Ukrainy [Patterns of the application of granulometric elements in micro aggregates in soils of Ukraine]. Ahrokhimiia i gruntoznavstvo, 61, pp. 22-31 [In Ukrainian].

11. Shylina, L. I., Shapoval, I. E., Yermolaiev, M. M. (2006). Zmina strukturno-ahrehatnoho stanu chornozemu typovoho pid vplyvom chynnykiv zemlerobstva [Changing the structural and aggregate state of black soil is typical under the influence of factors of agriculture]. Ahrokhimiia $i$ gruntoznavstvo, 2, pp. 188-190 [In Ukrainian].

Центило Л. В., Цюк А. А. Динамика изменений твердости почвы в зависимости от основной обработки

Цель статьи - выявить зависимости изменения динамики твердости почвы при применении различных систем основной обработки. 


\section{СІЛЬСЬКЕ ГОСПОДАРСТВО. ЕКОЛОГІЯ}

Методика исследования. Методологической основой послужили такие научные методы: анализ, синтез, полевой, статистический.

Результаты исследований. В статье приведены результаты исследований на черноземе типичном глубоком Правобережной Лесостепи Украины по изучению почвозашитной эффективности вариантов основной обработки на твердость почвы. Выяснено, что отвальная обработка не изменяет диапазона твердости чернозема типичного.

Применение мелкой безотвальной со щелеванием вызывает увеличение показателя твердости в нижней части пахотного слоя почвы. Различия по твердости наиболее выражены осенью, сразу после проведения основной обработки, а в весенне-летний период они салажсиват и, как правило, не достигают критических значений для выращивания культур.

Элементы научной новизны. Доказано, что твердость чернозема типичного глубокого малогумусного изменяется в зависимости от систем основной обработки почвьл. Применение отвальной обработки не изменяет показатели твердости почвы. Определено, что мелкая безотвальная обработка с одновременным щелеванием увеличивает величину твердости в нижней части пахотного слоя почвы.

Практическая значимость. Изучение динамики изменений твердости почвы по системам ее обработки осуществлялось на опытном поле Учебно-научно-инновационного центра агротехнологий ООО «Агрофирма Колос» (2011-2017 г2.) Сквирского района Киевской области в стационарном опьлте. Размер посевной площуади - $340 \mathrm{~m}^{2}$, учетной - $195 \mathrm{~m}^{2}$. Повторность трехкратная. Установлено, что применение отвальной обработки в севообороте не изменяет показателя твердости почвы. Применение мелкой безотвальной обработки одновременно со щзелеванием приводит к увеличению твердости почвы в среднем при вегетации кукурузы на зерно на 27 \%, лючерны - 1,74\% по сравнению с систематической отвальной обработкой. Однако в посевах пшениць озимой показатель твердости почвы при мелкой безотвальной с одновременным щелеванием снижался на 14,3\% по сравнению с отвальной обработкой.

Ключевые слова: твердость, система обработки, чернозем типичный, грунт.

Центило Леонид Васильевич - кандидат сельскохозяйственных наук, Национальный университет биоресурсов и природопользования Украины, ул. Героев Обороны, 15, г. Киев, 03041, Украина, e-mail: tsyuk@ukr.net.

Цюк Алексей Анатольевич - доктор сельскохозяйственных наук, Национальный университет биоресурсов и природопользования Украины, ул. Героев Обороны, 15, г. Киев, 03041, Украина, e-mail: tsyuk@ukr.net.

\section{Tsentylo $L$. V., Tsiuk $O$. A. The dynamics of soil firmness change depending on its basic cultivation}

The aim of the article is to determine the dependence of changes in the soil firmness dynamics at applying different systems of basic cultivation.

Methods of the research. The following scientific methods were the methodological basis: analysis, synthesis, field, statistical.

The research results. The results of research on typical black soil of the deep Right-Bank Forest-Steppe of Ukraine as to studying the soil protection effectiveness of basic cultivation variants on soil firmness are presented in the article. It was ascertained that the contour tillage does not change the range of firmness in typical black soil.

Applying shallow contour-free tillage with slitting causes the firmness increase in the lower part of the soil arable layer. Firmness differences are most of all expressed in autumn, right after the basic cultivation, and in the spring-summer period, they level and, as a rule, do not reach the critical values for growing crops.

The elements of scientific novelty. It was proved that the firmness of typical deep low-humic black soil is subject to changes depending on the systems of basic soil cultivation. The application of contour cultivation does not change soil firmness indices. It was determined that the shallow untreated cultivation with simultaneous slitting increases the degree of firmness in the lower part of the arable soil layer.

Practical significance. Studying the dynamics of soil firmness changes in relation to the systems of basic soil cultivation was carried out in the experimental field at the Training-Research-Innovation Center of Agro-technologies of the LLC "Agro-firm Kolos" (in 2011-2017) in Skvirsky district of Kyiv region as a 


\section{СІЛЬСЬКЕ ГОСПОДАРСТВО. ЕКОЛОГІЯ}

permanent experiment. The size of the sown area was $340 \mathrm{~m}^{2}$, the accounting area was $195 \mathrm{~m}^{2}$. The experiment was conducted in three replications. It was established that using contour cultivation in crop rotation did not change soil firmness index. The application of shallow untreated cultivation with simultaneous slitting led to increasing the soil firmness during the vegetation of maize for grain by $27 \%$ on the average, alfalfa $-1.74 \%$ as compared with systematic contouring. However, concerning wheat, the soil firmness index at the shallow untreated cultivation with simultaneous slitting decreased by $14.3 \%$ as compared with the contour cultivation.

Key words: firmness, system of cultivation, typical black soil, soil.

Tsentylo Leonid Vasylovych - Candidate (PhD) of Agricultural Sciences, National University of Life and Environmental Sciences of Ukraine, 15, Heroiv Oborony st., Kyiv, 03041, Ukraine, e-mail: tsyuk@ukr.net.

Tsiuk Oleksii Anatoliiovych - Doctor of Agricultural Sciences, National University of Life and Environmental Sciences, 15, Heroiv Oborony st., Kyiv, 03041, Ukraine, e-mail: tsyuk@ukr.net.

Стаття надійшла до редакції 28.02.2019 р.

Бібліографічний опис для цитування :

Центило Л. В., Цюк О. А. Динаміка змін твердості грунту залежно від його основного обробітку. Вісник ПДАА. 2019. № 1. С. 147-153.

DOI 10.31210/visnyk2019.01.16

(c) Центило Леонід Васильович, Цюк Олексій Анатолійович, 2019 